\title{
IJTIHAD HAKIM PENGADILAN AGAMA PADA PERKARA POLIGAMI
}

\author{
Ashabul Fadhli', Fathur Rahmi² \\ 1 Universitas Putra Indonesia YPTK Padang \\ e-mail: ashabulfadhli@gmail.com \\ 2 Universitas Islam Negeri Imam Bonjol Padang \\ e-mail: fathur_elrahmi@yahoo.com
}

\begin{tabular}{|l|l|l|}
\hline Submit: 08-10-2020 & $\begin{array}{l}\text { Direvisi: 28-20-2020, } \\
\text { 01-12-202 }\end{array}$ & Dipublish: 18-12-2020 \\
\hline
\end{tabular}

\begin{abstract}
This study discuss about the ijtihad of the Religious Court Judges in providing legal considerations on cases of polygamy permit applications. Every decision on a polygamy permits that granted or not granted proves that there are efforts and hard work of judges in realizing and even interpreting primary and secondary sources of law in the trial process. One of the copies of the case the writer found the Judge giving strict consideration between the necessity referring to the statutory basis or to the basis of fiqh. As a legal research, this research carries out library research using the juridical-normative approach. This study takes data from a copy of the case in the Supreme Court's decision3 thematically. The results of this study indicate that the judge's Ijtihad in setting aside the primary legal basis and prioritizing figh considerations, even the opinion of Islamic law experts, aims to attract the benefit of the applicant's household. This finding confirms that the judge's ijtihad has an important role in producing legal decisions.
\end{abstract}

Kata kunci: ijtihad, pertimbangan hukum, putusan hukum

\section{PENDAHULUAN}

$\mathcal{A}$ rgumen ketidakpastian hukum menyangkut ambivalensi pada materi hukum, yang satu sisi berasas monogami, namun pada sisi lain dibolehkan poligami memerlukan interpretasi pada pelaksanaannya. (Anshary, 2010) Argumen ini muncul berdasarkan ketentuan pada Pasal 3 ayat (1) bahwa perubahan makna untuk menjadi poligami hanya dapat diwujudkan ketika perkawinan poligami dikehendaki oleh orang-orang yang bersangkutan. Pada konteks lain, pasal tersebut diinterpretasikan sebagai celah hukum bagi warga negara untuk melakukan pernikahan poligami. Mes- kipun poligami diperbolehkan, tetapi pelaksanaannya secara yuridis dipersulit atau dibatasi dengan sekelumit aturan ketat dan syarat-syarat tertentu. (Mardani, 2010: 96) Bahkan, pada temuan dari sejumlah salinan perkara yang berhasil dikumpulkan, tidak semua permohonan poligami dikabulkan oleh hakim. Bagi pemohon yang permohonannya dikabulkan, sesungguhnya putusan majelis hakim berangkat dari proses pertimbangan yang kompleks.

Untuk menghasilkan putusan yang benar-benar dipandang baik dan maslahat bagi setiap Pemohon, majelis hakim Pengadilan Agama memiliki kewenangan tersendiri dalam menyelenggarakan 
peradilan sebagaimana yang diatur dalam Undang-Undang Nomor 48 Tahun 2009 tentang Kekuasaan Kehakiman. Melalui aturan tersebut, hakim juga terikat dengan kebutuhan untuk menggali, mengikuti dan memahami nilai-nilai hukum dan rasa keadilan yang hidup dalam masyarakat. Atas dasar itu, terkait dengan adanya temuan perkara yang tidak ditemui aturan hukum kongkritnya di dalam perundang-undangan, maka dapat ditemui melalui pendekatan metode ushuliyah atau fiqhiyyah. Dalam hal ini hakim dapat menerapkan asas Ius Contra Legem dalam putusan melalui upaya ijtihad, yaitu dalam Perkara izin poligami. Hakim menurut Undang-Undang tidak boleh menolak suatu perkara yang diajukan kepadanya dengan alasan tidak ada hukumnya atau hukumnya tidak jelas, melainkan harus menerima, memeriksa dan mengadilinya.

Berangkat dari argumen di atas, artikel ini disuguhkan guna melihat bagaimana usaha dan ijtihad Hakim Pengadilan Agama dalam memberikan pertimbangan hukum pada perkara poligami hingga berakhir pada putusan mengabulkan atau menolak. Menariknya, pada tulisan ini akan terlihat bagaimana hakim menyandingkan hukum primer dengan hukum figh melalui metode Ijtihad. Hakim menambahkan pertimbangan kaidah fikih/ushul fikih dalam tindakan contra legem sebagai penguatan isi putusan, sebagai bagian dari bentuk usaha Hakim dalam membumikan hukum syara' melalui putusan hukums.

\section{METODE PENELITIAN}

1. Jenis Penelitian
Untuk menyelesaikan isu hukum dalam penelitian ini maka jenis penelitian ini adalah "Metode Penelitian Hukum Normatif atau Metode Penelitian Hukum Doktrinal". (R. Hanitjo Soemitro, 1985) Metode ini merupakan metode kepustakaan Anglo-Amerika yang disebut dengan legal research. Tipe utama dari Metode Penelitian Hukum Normatif ini adalah "penelitian yang berupa usaha penemuan hukum inconcreto yang sesuai untuk diterapkan guna menyelesaikan suatu perkara hukum tertentu. (Ronny Hanitjo Soemitro, 1985) Pada penelitian ini diambil beberapa kasus pada putusan sejumlah pengadilan agama di Indonesia yang memiliki kesamaan perkara yaitu izin poligami.

2. Sumber Penelitian Hukum.

Sumber-sumber penelitian hukum dapat dibedakan menjadi sumbersumber penelitian hukum primer dan bahan-bahan hukum sekunder. Sumbersumber penelitian hukum ini yaitu:

a. Bahan hukum primer yaitu perundang-undangan yang terdiri dari Undang-Undang no.1/1974 tentang Perkawinan, PP no.9/1975 tentang Pelaksanaan UU no.1/1974, UU no.7/1989 tentang Peradilan Agama jo. UU No. 3 tahun 2006 tentang Peradilan Agama (One Roof System), jo. UU no. 50 tahun 2009 tentang Peradilan Agama, Intruksi Presiden No.1/1991 Tentang Kompilasi Hukum Islam.

b. Bahan-bahan sekunder berupa semua publikasi tentang hukum (buku teks penulis dari Eropa Kontinental, yaitu Belanda dan 
buku-buku penulis AngloAmerika). Di samping buku teks bahan hukum sekunder dapat berupa tulisan-tulisan tentang hukum seperti jurnal, artikel, karya ilmiah seperti skripsi, tesis, disertasi, dan komentar atas putusan Pengadilan. Kegunaan bahan hukum sekunder adalah memberikan kepada peneliti semacam "petunjuk" ke arah mana peneliti melangkah/ sebagai inspirasi bagi penulis. Dalam hal ini adalah salinan perkara yang berhasil dikumpulkan tentang putusan poligami.

3. Karakteristik Penelitian Hukum

Kemudian informasi-informasi penulis peroleh, penulis olah dengan menggunakan beberapa metode, yaitu:

a. Induktif yaitu suatu metode dalam melakukan penelitian yang diambil dari informasi khusus kemudian dari informasi yang khusus dan konkrit itu ditarik generalisasigeneralisasi yang bersifat umum (Hadi, 1985). Metode induksi berangkat dari fakta (gejala) tertentu yang diabstraksikan untuk mencari prinsip apa yang telah dikuasainya sehingga dapat dibangun suatu hipotesis. Apabila gejala tersebut sudah dikumpulkan barulah informasi tersebut dianalisis atau diolah. Dalam hal ini penelitian beranjak dengan menelaah efektifitas aturan hukum dalam kehidupan masyarakat dan kepatuhan masyarakat dalam menjalankan hukum.

b. Deduktif yaitu suatu metode pembahasan yang bertitik tolak dari keterangan-keterangan dan pengetahuan yang bersifat umum kemudian berdasarkan keterangan dan pengetahuan yang bersifat umum itu penulis mengarahkan kepada hal-hal yang bersifat khusus. Secara khusus karakteristik penelitian ini dimulai dengan memperhatikan premis mayor. Premis mayor dalam penelitian ini adalah UU No. 1 Tahun 1974 tentang Perkawinan Pasal 3, 4, 5 dan pasal 65 UU 1/1974 dan KHI Pasal 55-59 dan pasal 82, Pasal 7 Peraturan Pemerintah No. 53 Tahun 2010 Tentang Disiplin Pegawai Negeri Sipil. Sedangkan premis minornya adalah banyaknya terjadi poligami sirri dan tidak tercatat yang menimbulkan masalah sosial baru dan kasus hukum baru. Sedangkan isu hukum yang menjadi topik pembicaraan adalah pertimbangan hakim pada alasan izin poligami yang dikabulkan atau ditolak.

\section{Teknik Analisi Data}

Untuk menyelesaikan penelitian ini dilakukanlah analisa kualitatif. Analisa kualitatif pada dasarnya menggunakan pemikiran logis, analisa dengan logika, dengan induksi, deduksi dan analogi. Analisis deskriptif kualitatif digunakan karena teori masih menjadi alat penelitian sejak memilih dan menemukan masalah, membangun hipotesis maupun melakukan pengamatan di lapangan sampai dengan menguji data (Bungin, 2007).

5. Pendekatan Dalam Penelitian Hukum. 
Pendekatan-pendekatan yang digunakan yaitu:

a. Pendekatan Undang-Undang (statute approach).

Dilakukan dengan menelaah Undang-Undang yang berkaitan dengan isu hukum yang sedang diteliti. Dalam hal ini penulis menelaah UU No. 1 Tahun 1974 tentang Perkawinan Pasal 3, 4, 5 dan pasal 65 UU 1/1974 dan KHI Pasal 55-59 dan pasal 82 dan Pasal 7 Peraturan Pemerintah No. 53 Tahun 2010 Tentang Disiplin Pegawai Negeri Sipil.

b. Pendekatan Kasus (case approach)

Dilakukan dengan cara melakukan telaah terhadap kasus-kasus yang berkaitan dengan isu yang sedang dihadapi yang telah menjadi putusan pengadilan yang telah mempunyai kekuatan hukum tetap. Yang menjadi bahan pokok di dalam pendekatan kasus adalah ratio decidendi atau reasoning yaitu pertimbangan pengadilan untuk sampai kepada suatu putusan. Penelitian kasus ini bertujuan untuk melihat bagaimana usaha dan ijtihad Hakim Pengadilan Agama dalam memberikan pertimbangan hukum pada perkara poligami dan alasan contra legem dalam putusan hakim.

\section{POLIGAMI DALAM ATURAN HUKUM DI INDONESIA}

Pedoman tentang pelaksanaan poligami di Indonesia diatur dalam Undang-Undang Nomor 1 Tahun 1974 tentang Perkawinan pasal 3 ayat (2) disebutkan bahwa "pengadilan dapat memberi izin kepada seorang suami untuk beristri lebih dari seorang apabila dikehendaki oleh pihak-pihak yang bersangkutan". Izin poligami dilakukan dengan memenuhi persyaratan alternatif (Mardani, 2010:97) (salah satu dari kondisi istri) pada pasal 4 (2) Undang-Undang Perkawinan bahwa Pengadilan hanya memberi izin kepada suami yang akan beristri lebih dari seorang apabila Istri tidak dapat menjalankan kewajibannya sebagai istri; atau Istri mendapat cacat badan atau penyakit yang tidak dapat disembuhkan; dan atau Istri tidak dapat melahirkan keturunan. Di samping itu ada persyaratan komulatif. (Manan, 2006) yang wajib dipenuhi secara total oleh suami sebagaimana dijelaskan dalam pasal 5 ayat (1) yaitu Adanya persetujuan dari istri/istri-istri; Adanya kepastian bahwa suami mampu menjamin keperluan-keperluan hidup istri-istri dan anak-anak mereka, Adanya jaminan bahwa suami akan berlaku adil terhadap istri dan anak-anak mereka. Persetujuan dari istri/istri-isri akan gugur atau tidak diperlukan lagi ketika isti atau istri-istri tidak mungkin lagi dimintai persetujuannya dikarenakan beberapa keadaan atau istrinya dikatakan/dianggap ghaib/hilang/tidak ada kabar dalam kurun waktu 2 (dua) tahun, atau terdapat sebab-sebab lain yang mengharuskan adanya pertimbangan Pengadilan.

Persoalan poligami juga terdapat dalam Kompilasi Hukum Islam, yang digunakan hakim di pengadilan sebagai pedoman dalam menyelesaikan masalah di bidang tersebut. Seperti diatur dalam pasal 55-59. Pasal 55 mensyaratkan maksimal empat orang istri dalam berpoligami dan kemampuan berlaku adil terhadap istri dan anak-anaknya. Apabila 
syarat keadilan tidak mungkin terpenuhi, suami cukup beristri seorang saja.

Pasal 56-59 KHI menjelaskan bahwa suami yang hendak berpoligami harus mendapat izin dari Pengadilan Agama. Jika istri tidak mau memberikan persetujuan, maka Pengadilan Agama berwenang dalam menetapkan pemberian izin setelah memeriksa dan mendengar istri di persidangan Pengadilan Agama, dan terhadap penetapan ini istri atau suami dapat mengajukan banding atau kasasi.

Jika dalam putusan hakim menetapkan memberikan izin poligami bagi suami, maka sesuai Undang-Undang 1 Tahun 1974 tentang Perkawinan pasal 65 maka Suami wajib memberikan jaminan hidup yang sama kepada semua isteri dan anaknya; Isteri yang kedua dan seterusnya tidak mempunyai hak atas harta bersama yang telah ada sebelum perkawinan dengan isteri kedua atau berikutnya itu terjadi; Semua isteri mempunyai hak yang sama atas harta bersama yang terjadi sejak perkawinannya masing-masing. KHI pasal 82 menambahkan, suami yang berpoligami wajib menyediakan tempat tinggal dan biaya hidup bagi masingmasing istri secara berimbang menurut besar kecilnya jumlah keluarga yang ditanggung masing-masing istri, kecuali jika ada perjanjian perkawinan. Jika istriistri rela dan ikhlas, suami dapat menempatkan istri-istrinya dalam satu tempat kediaman.

Berdasarkan uraian di atas, dapat diketahui bahwa hukum materil tentang Perkawinan telah memberikan aturan yang jelas tentang poligami. Diharapkan akan menumbuhkan kesadaran bagi masing-masing suami istri akan kewajiban masing-masing dalam rumah tangga, sehingga tujuan perkawinan untuk membentuk rumah tangga yang kekal berdasarkan Ketuhanan Yang Maha Esa dapat direalisasikan.

\section{KETERLIBATAN PENGADILAN AGAMA PADA PERKAWINAN POLIGAMI OLEH PEGAWAI NEGERI SIPIL}

Ketegasan aturan hukum berpoligami di Indonesia sudah dibuktikan melalui pernyataan bahwa pengadilan hanya dapat memberi izin kepada seorang suami untuk beristri lebih dari seorang apabila dikehendaki oleh pihak-pihak yang bersangkutan. Alasan yang diajukan oleh pihak suami mesti alasan yang dapat diterima oleh hukum, khususnya bagi pihak-pihak yang tersangkut dengan perkawinan poligami. Tidak ada perbedaan pandangan hukum secara umum bagi laki-laki yang hendak berpoligami dalam hal hak dan kewajiban sebagai suami. Namun secara khusus, pembedaan hukum tersebut baru akan terlihat ketika suami berstatus sebagai pegawai negeri sipil (PNS). Ketentuan ini semakin menunjukkan bahwa aturan poligami memang dipersulit. (Hadikusuma, 1990)

Kekhususan aturan hukum yang diberikan pada PNS untuk berpoligami ditujukan agar suami yang menyandang status PNS dapat tunduk pada aturan yang sudah ada. Secara umum seperti yang dijelaskan dalam Peraturan Pemerintah Nomor 10 tahun 1983 tentang izin berpoligami dan perceraian bagi PNS sebagaimana yang telah diubah dalam 
peraturan pemerintah Nomor 45 tahun 1990, yaitu mendapat Izin atasan untuk berpoligami, namun bagi Pegawai Negeri Sipil wanita tidak diizinkan untuk menjadi istri kedua/ketiga/keempat. Izin poligami tersebut diajukan secara tertulis dengan mencantumkan alasan-alasan yang mendasari permintaan izin poligami dengan memperhatikan persyaratan alternatif dan komulatif sebagaimana yang dijelaskan dalam UU 1 Tahun 1974 tentang Perkawinan pasal 4 dan 5 .

Ketentuan di atas sejatinya mengatur tentang cara, prosedur, syarat pelaksanaan hingga hal-hal lain yang dianggap penting. Hal ini menandakan bahwa izin berpoligami bagi suami dengan status PNS dipandang wajib. Pada prosesnya, izin berpoligami diperlukan dalam bentuk tertulis dari pejabat atau atasannya lengkap dengan dasar alasan. (Muchali, 2005) Adapun atasan atau pejabat yang dimaksud adalah Pejabat yang sudah eselon IV atau setingkat dengan itu. Izin ini dapat diperoleh melalui pejabat yang bersangkutan sesuai dengan domisili PNS dengan meneruskannya kepada atasan atau pejabat yang yang berwenang dalam kurun waktu maksimal tiga bulan sejak mulai tanggal permintaan izin itu diterima dan diproses. Baru kemudian yang bersangkutan dapat mengajukan permohonan poligaminya ke Kantor Pengadilan Agama untuk diproses secara hukum dan selanjutnya menunggu putusan. Apabila permohonan tersebut dikabulkan, barulah PNS yang bersangkutan dapat berpoligami dan perkawinan poligaminya dinyatakan sah demi hukum. Dengan ini, Izin dari atasan bagi PNS yang hendak berpoligami merupakan suatu keharusan. PNS yang berpoligami diam-diam akan diberikan sanksi sebagaimana tertuang dalam Pasal 7 Peraturan Pemerintah No. 53 Tahun 2010 Tentang Disiplin Pegawai Negeri Sipil dalam tingkat hukum yang berbedabeda yaitu hukuman disiplin ringan, hukuman disiplin sedang dan hukuman disiplin berat.

Dalam temuan (Budiharjo, 2013) perkawinan poligami yang melanggar ketentuan Peraturan Pemerintah No. 53 Tahun 2010 di lingkungan PNS seperti yang dilakukan secara diam-diam atau sirr, setelah itu menginginkan diajukannya isbat nikah ke Pengadilan Agama, maka yang bersangkutan akan diberikan sanksi berupa denda atau hukuman badan.

Menurut Penulis, dalam hal sanksi inilah letak pembaruan hukum Hakim. Poligami sebagai putusan declaratoir dengan jenis perkara volunter yaitu perkara yang tidak mengandung sengketa, biasanya putusan pengadilan agama hanya berkisar tentang menetapkan saja tentang keadaan hukum, membatalkan atau tidak memberi izin pada perkara yang diajukan. Namun dalam kasus ini, demi menegakkan keadilan dan memelihara perkawinan yang telah berlangsung, hakim berinovasi dengan memberikan hukuman denda atau hukuman badan, bukan hukuman disiplin lagi, yang biasanya hukuman denda dan hukuman badan biasa ditemukan dalam putusan yang bersifat condemnatoir dalam hukum perdata dan lazim dalam hukum pidana dalam pelanggaran tindak pidana umum atau tindak pidana khusus. 


\section{IJTIHAD HAKIM PENGADILAN AGAMA DALAM MEWUJUDKAN KEPASTIAN HUKUM}

Perwujudan hak suami dengan menikahi lebih dari satu orang istri, telah diatur khusus melalui Undang-Undang Perkawinan dengan syarat-syarat yang dipandang menyulitkan. Permohonan izin poligami di Pengadilan Agama adalah pintu gerbang bagi siapapun pemohon yang menginginkan perkawinan poligaminya dikabulkan. Para pemohon yang mengajukan permohonan izin poligami dengan alasan apapun, atau dimohonkan dalam bentuk permohonan istbat nikah dikarenakan telah menikah sirri terlebih dahulu, sama-sama akan diproses dengan pertimbangan-pertimbangan hukum yang semuanya berangkat melalui usaha atau ijtihad hakim Pengadilan Agama.

Ijtihad secara umum didefenisikan sebagai usaha berfikir yang dilakukan secara optimal dan bersungguh-sungguh dalam upaya menggali hukum Islam dari sumber atau asalnya, guna memunculkan jawaban dari persoalan-persoalan hukum yang timbul di tengah masyarakat. Pada pemahaman ini, ijtihad hadir untuk mengantisipasi tantangan-tantangan baru yang selalu saja bermunculan seiring berkembangnya zaman. (Tiwana, 1972) Sehubungan peran sebagai hakim Pengadilan Agama, maka hakim senantiasa dituntut untuk berfikir dalam tujuan untuk mengambil suatu kebijakan yang memiliki nilai maslahat. Artinya, setiap usaha hakim dalam menyelenggarakan peradilan berpijak pada landasan pemikiran yang memiliki kekuatan hukum serta dapat dipertanggungjawabkan.
Sidang perkara izin poligami dipandang sebagai salah satu perkara yang membutuhkan ijtihad hakim dari menerima, memeriksa, mengadili dan menyelesaikan setiap perkara yang diajukan. Ijtihad hakim dipandang sebagai suatu keharusan karena dari banyaknya permohonan poligami yang diajukan, tidak semua aturan primernya terdapat dalam peraturan perundangundangan. Karena itu, hakim memiliki kewajiban untuk menggali, mengikuti dan memahami nilai-nilai hukum dan rasa keadilan yang hidup di tengah masyarakat. (UU Nomor 48 Tahun 2009 Pasal 5)

Perwujudan dari kewajiban itu, dilaksanakan hakim melalui Ijtihad untuk menggali hukum-hukum (syara') yang bersifat amaliyah dari dalil-dalil yang terperinci. (Zahra, n.d.) Dalam hal ini, sebagai seseorang yang memiliki pengetahuan mendalam terkait hukum syar'i, khususnya menyangkut hukum perkawinan, maka seorang hakim didorong untuk berijtihad berdasarkan perkara hukum yang masuk. Hakim juga tidak harus selalu berpegang pada peraturan-peraturan yang tertulis saja, dalam keadaan demikian tepatlah apabila hakim diberi kebebasan untuk mengisi kekosongan hukum. (Aisyah, 2018) Apalagi, ketika hakim dihadapkan pada perkara-perkara yang belum ditegaskan secara kongkrit mengenai aturan hukumnya di dalam perundang-undangan. Untuk menghasilkan keadilan hukum bagi yang berperkara, hakim dapat bertindak contra legem, dengan catatan bahwa tindakan contra legem tersebut hanya boleh dilakukan apabila terdapat suatu perkara yang tidak memiliki aturan 
yang jelas ataupun tidak terdapat aturan yang mengatur persoalan hukum tersebut. (Mushthofa, 2019)

Bagir Manan melalui tulisan XX menyebutkan bahwa rumusan undangundang sebagai hukum tertulis bersifat umum dan sangat sedikit kemungkinan untuk dapat menampung secara pasti setiap peristiwa hukum. Menurut Bagir Manan, peran hakim pada situasi ini akan muncul, tampak dan terlihat yaitu dengan menghubungkan dan menyambungkan peristiwa hukum yang kongkrit dengan ketentuan hukum yang abstrak. (Rogaiyah, 2010)

Dengan begitu, tindakan contra legem ini menjadikewenangan bagi hakim pengadila agama sesuai dengan ketentuan pasal 5 ayat (1) tentang Undang-Undang Nomor 48 Tahun 2009 tentang Kekuasaan Kehakiman yang mewajibkan hakim untuk menggali, mengikuti dan memahami nilai-nilai hukum dan rasa keadilan yang hidup dalam masyarakat. Oleh hakim Pengadilan Agama, kewenangan ini dapat diwujudkan melalui upaya ijtihad.

Ijtihad hakim Pengadilan Agama akan menjadi esensi yang sangat dibutuhkan untuk bisa menghasilkan putusan-putusan baru yang sedang dihadapi oleh para pencari hukum, terutama pada perkara yang belum ada keterangan hukumnya atau belum memiliki aturan hukum yang jelas.

Adapun esensi ijtihad yang diwujudkan oleh Hakim dengan menemukan prinsip dasar, makna universal dan tujuan hukum yang kemudian direlevansikan berdasarkan tujuan mashlahat. Cara ini dikenal dengan maqashid-based Ijtihad atau maqashid sebagai dasar Ijtihad. (Mu'ammar, et. al, 2012)

Bentuk ijtihad tersebut diantaranya dapat ditinjau dari ijtihad hakim Pengadilan Agama Rembang pada putusan Nomor 850/Pdt.G/2019/PA.Rbg tentang permohonan seorang suami untuk diizinkan hendak menikah lagi (poligami) dengan calon pilihannya dikarenakan istrinya sebagai termohon tidak kuat dalam melayani pemohon untuk dapat menjalankan kewajiban sebagai seorang istri dikarenakan keinginan hasrat sexualitas pemohon tinggi. Alasan pemohon kemudian mendorong hakim Pengadilan Agama Rembang untuk memberikan pertimbangan hukum yang akan digunakan dalam mengabulkan permohonan poligami dengan berpedoman kepada kaidah-kaidah fiqh. Pada putusan ini, melalui pertimbangan hukum pada putusan tertuang bahwa apabila permohonan poligami pemohon ditolak, maka mafsadat yang dimunculkan kedepan ditakutkan akan lebih besar dibanding maslahat yang akan diterima. Sebab, pihak suami sebagai pemohon mengkhawatirkan dirinya akan melakukan perbuatan yang dilarang oleh norma agama apabila suami sebagai pemohon tidak melakukan poligami. Dengan begitu, putusan hukum yang telah ditetapkan hakim melalui perkara di atas, berpijak pada alasan bahwa telah terpenuhinya syarat yang dicantumkan dalam Undang-Undang Nomor 1 Tahun 1974 dan juga mempertimbangkan kemaslahatan suami. (Handayani et al., 2019)

Permohonan izin poligami serupa juga penulis temukan dalam salinan putusan nomor 452/Pdt.G/2018/PA.Skh 
yang menerangkan bahwa Termohon sebagai istri dari Pemohon selama bertahun-tahun mengidap penyakit tumor payudara. Termohon sudah tidak sanggup melayani Pemohon dalam melakukan hubungan selayaknya suami istri (seksualitas). Pemohon mempunyai hasrat biologis yang tinggi dan jika tetap dipaksakan Termohon merasa sangat tersiksa. Pemohon dan Termohon selama ini sudah berusaha untuk saling menyabarkan diri, namun hal tersebut justru membuat Termohon merasa tersiksa sehingga Pemohon tidak bisa menyalurkan hasrat seksualitasnya secara menyeluruh. Termohon merasa adanya kekurangan/ keadaan tersebut sehingga tidak bisa melaksanakan kewajibannya sebagaimana seorang istri, maka Termohon mengijinkan kepada Pemohon untuk menikah lagi.

Dalam pertimbangan hukumnya, Hakim menimbang bahwa dalam Islam diperbolehkan seorang laki-laki untuk melakukan poligami sebagaimana Firman Allah dalam Surat An Nisa': 3 yang artinya:

“...maka kawinilah wanita-wanita yang kamu senangi dua, tiga atau empat, kemudian jika kamu takut tidak dapat berlaku adil, maka kawinilah seorang saja". (QS. An Nisa' [4]: 3)

Hakim dalam putusannya juga menambahkan pendekatan ushul melalui kaidah-kaidah fiqh guna meraih maslahat bagi pemohon poligami (Muamar Irfan Nurhadi, 2014). Kaidah fiqh tersebut berbunyi:

$$
\text { در ءالمفاسد اولى عن جلب المصالح }
$$

"Menolak mafsadat atau keburukan lebih utama dibanding meraih maslahat atau kebaikan".

Melalui dalil hukum di atas, Hakim Pengadilan Agama Sukoharjo menimbang bahwa alasan Pemohon mengajukan permohonan untuk kawin lagi (poligami) pada pokoknya karena Pemohon masih mempunyai dorongan biologis relatif kuat, sementara Termohon sudah tidak ada hasrat/kemauan untuk melayani hubungan suami-isteri karena telah lama mempunyai penyakit kanker payudara. Apabila Pemohon tidak menikah lagi dikhawatirkan akan mudah tergoda untuk melakukan perbuatan dosa dan isteri pemohon juga telah menyetujui apabila Pemohon menikah lagi (poligami). Sekiranya, esensi dari ijtihad Hakim Pengadilan Agama Rembang juga tidak jauh berbeda dengan putusan Hakim Pengadilan Agama Sukoharjo. Pada aspek maslahat, izin poligami diperoleh suami dengan ketentuan bahwa suami terpelihara jiwa dan raganya dari peluang akan terjadinya perbuatan zina. (M. Ichsan, 2018)

Selanjutnya, salinan putusan Pengadilan Agama Brebes Nomor 304/Pdt.P/2020/PA.Bbs penulis dapati bahwa permohonan poligami didasarkan karena istrinya sebagai termohon yang saat putusan ini dikeluarkan telah dikaruniai dua orang anak bersama pemohon, bahwa termohon telah menentukan sikap akan lebih fokus mengurus buah hati pemohon dan termohon yang masih kecil dan tinggal di Brebes. Domisili termohon yang menetap di Brebes dirasa berjauhan dengan Pemohon yang bekerja dan tinggal di Jakarta sebagai pegawai hotel. Berjauhan 
tempat tinggal ini berdampak antara Pemohon dan Termohon jarang dalam melakukan hubungan suami istri, sehingga hal tersebut menjadi beban psikologis bagi pemohon.

Berdasarkan jawaban Termohon yang tidak membantah atas keterangan dari pemohon, bahwa termohon mengerti akan kebutuhan biologis pemohon, maka termohon rela dan ikhlas apabila pemohon memiliki istri lagi dan mendampingi pemohon di Jakarta. Atas dasar itu, kemudian hakim telah berusaha mendamaikan dan menasehati pemohon agar tidak mengajukan izin poligami tetapi tidak berhasil. Menariknya, masih dalam pertimbangan hukum majelis hakim, hakim berhasil memberikan saransaran mengenai perkawinan pemohon dan termohon, maka melalui kuasa pemohon akhirnya perkara tersebut dicabut oleh kuasa pemohon. Atas dasar itu pula, majelis hakim menyatakan sah dicabutnya permohonan tersebut.

Perkara poligami selanjutnya penulis menemukan dari putusan Pengadilan Tinggi Agama Mataram Nomor 0093/Pdt.G/2014/PTA.Mtr yang memeriksa dan mengadili perkara itsbat nikah Poligami pada tingkat banding yang mempertemukan Pembanding I (49 tahun) yang bekerja sebagai PNS (Pengawas PAI TK/SD) dan Pembanding II (39 tahun) yang juga bekerja sebagai PNS (Guru SMP) yang sama-sama tinggal di Kecamatan Raba, Kota Bima. Pembanding dalam hal ini melawan Terbanding (51 tahun) yang bekerja sebagai Ibu Rumah Tangga. Pemohon I/Pembanding I dan Pemohon II/ Pembanding II memohonkan agar pernikahan mereka dapat dinyatakan sah demi hukum. Sebab, saat perkara ini diajukan, yang bersangkutan mengakui belum memiliki Buku Nikah yang sah. Adapun dari sisi Termohon/Terbanding sebagai isteri pertama Pemohon I/Pembanding I diketahui sudah memberikan izin kepada suaminya untuk menikah lagi dengan Pemohon II/Pembanding II. Sedangkan dari sisi Pemohon II/Pembanding II sekiranya tidak pula terdapat cacat hukum yang sekiranya dapat merusak sahnya perkawinannya dengan Pemohon I / Pembanding I, dikarenakan saat itu Pemohon II / Pembanding II masih berstatus gadis dan belum menjadi PNS.

Pada perkara sebelumnya yang diadili oleh Pengadilan Agama Bima Nomor 0663/Pdt.G/2014/PA.Bm telah menolak permohonan Pemohon atau Pembanding. Pada proses banding, Pengadilan Tinggi Agama Mataram telah memeriksa dan menimbang bahwa Pemohon I/Pembanding I dan Pemohon II/ Pembanding II yang keduanya adalah Pegawai Negeri Sipil (PNS), telah mengajukan permohonan Isbat Nikah Poligami ke Pengadilan Agama Bima. Pemohon I/Pembanding I saat itu dinyatakan tidak patuh hukum dikarenakan tidak mengikuti aturan perkawinan poligami bagi PNS dengan adanya keharusan meminta izin pada atasan. Hal ini sesuai dengan ketentuan Peraturan Pemerintah Nomor 45 tahun 1990 Pasal 4 ayat (1) atas tentang perubahan Peraturan Pemerintah Nomor 10 tahun 1983. Begitu juga dengan ketentuan persyaratan yang harus dipenuhi terlebih dahulu bagi orang yang hendak melangsungkan pernikahan poligami menurut ketentuan UndangUndang nomor 1 tahun 1974, jo Peraturan Pemerintah Nomor 10 tahun 1983 jo Peraturan Pemerintah Nomor 45 tahun 
1990, terutama mengenai konsekuensi hukum bagi calon isteri yang berstatus PNS untuk menjadi isteri kedua atau ketiga.

Pada sudut pandang lain, sebelum mengajukan Banding ke Pengadilan Tinggi Agama Mataram, diketahui bahwa Pengadilan Agama Bima Nomor 0663/Pdt.G/2014/PA.Bm telah menolak permohonan Pemohon atau Pembanding. Putusan ini membuktikan bahwa tidak semua permohonan untuk mengajukan permohonan poligami dikabulkan. Melalui putusan hukum Pengadilan Agama Bima diketahui bahwa permohonan izin poligami Pemohon I dan Pemohon II tidak dikabulkan dikarenakan Pemohon I belum memenuhi ketentuan izin poligami bagi PNS. Perlu ditegaskan, bahwa Undang-Undang Nomor 1 tahun 1974 tentang Perkawinan, jo Peraturan Pemerintah Nomor 10 tahun 1983 jo Peraturan Pemerintah Nomor 45 tahun 1990, telah memberikan ketentuan hukum khusus bagi PNS akan mengajukan permohonan poligami.

Pertimbangan hukum oleh majelis hakim dari perkara di atas sekiranya relevan dengan ulasan yang telah penulis ulas sebelumnya bahwa kekhususan aturan hukum yang diberikan pada PNS untuk berpoligami ditujukan agar suami yang menyandang status PNS dapat tunduk pada aturan yang sudah ada. Bagi PNS yang kedapatan tidak patuh atau melanggar aturan hukum dengan melakukan perkawinan poligami secara diam-diam atau dalam bentuk perkawinan lain yang tidak dibenarkan, maka Negara akan memberikan sanksi khusus yaitu sangksi disiplin pegawai negeri sipil. Disiplin pegawai negeri sipil ini tertuang dalam Pasal 7 Peraturan Pemerintah No. 53 Tahun 2010 Tentang Disiplin Pegawai Negeri Sipil dalam tingkat hukum yang berbeda-beda yaitu hukuman disiplin ringan, hukuman disiplin sedang dan hukuman disiplin berat.

Berlanjut pada putusan Pengadilan Agama Sleman Nomor 790/Pdt. G/2013/PA.SMN diketahui juga pernah menolak permohonan pemohon izin poligami. Pada salinan putusan perkara ini ditemukan bahwa alasan permohonan izin poligami dilakukan atas dorongan istri pertama. Dorongan istri yang dimaksud berangkat dari kondisi istri pemohon secara fisik yang tidak lagi sehat seperti dahulunya. Hakim berpandangan, disamping mengacu pada pasal 4 ayat 2 Undang-Undang Perkawinan sebagai standar hukum pemberian izin poligami, majelis hakim lebih mengacu pada upaya mewujudkan maslahat para pihak dengan dukungan dari istri sebagai termohon yang dengan ikhlas mendorong suaminya sebagai pemohon untuk menikah lagi. Artinya, apabila ditelusuri sesuai regulasi yang ada, sebagaimana ketentuan izin berpoligami pada Undang-Undang perkawinan, pemohon pada perkara ini idealnya diadili dengan hasil Pengadilan Agama Sleman mengabulkan permohonan pemohon. Namun rupanya majelis Hakim memiliki pertimbangan lain dengan tidak mengikuti jalur UndangUndang Perkawinan yang sudah dijelaskan secara eksplisit dan lebih mengedepankan pertimbangan fiqh dalam mewujudkan maslahat.

Pada penelitian terdahulu (Budiharjo, 2013), juga ditemukan bahwa perkawinan poligami dipraktekkan oleh 
seorang guru yang bekerja pada salah satu Sekolah Menengah Pertama di Kabupaten Grobogan. Kapasitasnya sebagai Pegawai Negeri Sipil mengaharuskan pemohon untuk mendapatkan izin poligami dari Bupati dengan mengajukan permohonan pengajuan izin ke Bupati ditujukan ke kantor Badan Kepegawaian Daerah (BKD). Adapun alasan pemohon bahwa istri tidak dapat melahirkan keturunan. Untuk memperkuat alasan tersebut di depan Hakim Pengadilan Agama, pemohon melampirkan bukti dari surat dokter yang menyatakan bahwa si istri tidak dapat melahirkan keturunan atau mandul.

Berangkat dari perkara-perkara yang disidangkan oleh hakim Pengadilan Agama dan Pengadilan Tinggi Agama di atas, dapat diketahui bahwa selain menggunakan dasar hukum primer yaitu Undang-Undang Perkawinan dalam memberikan pertimbangan hukum perkara poligami, hakim juga selalu menyandingkan hukum primer tersebut dengan hukum fiqh melalui metode Ijtihad. Hakim terlihat masih terpaut memberikan pertimbangan hukum yang berkenaan dengan penerapan kaidah ushuliyah dan fiqhiyah.

Bahkan dapat dilihat dengan jelas, adanya tindakan contra legem yang diterapkan Hakim dengan mengenyampingkan landasan hukum primer dan mendahulukan pertimbangan fiqh. Dasar pertimbangan hukum oleh hakim memuat pertimbangan yang bersifat mashlahat dan substantif. Artinya, terdapat kecendrungan pada putusan hakim Pengadilan Agama dalam memutus perkara, yaitu hakim senantiasa menyesuaikan dengan koridor teori tujuan penetapan hukum melalui metodologi hukum islam.

Ijtihad hakim ini dipandang sebagai usaha seorang mujtahid dalam menetapkan hukum syara' atas peristiwa-peristiwa hukum yang tidak ada nashnya secara khusus yang diatur di dalam dalil. Artinya, Ijtihad hakim memiliki peranan penting dalam menghasilkan putusan hukum serta wujud dari eksistensi figh sehingga dapat melahirkan putusan progresif yang maslahat.

Putusan Pengadilan Tinggi Agama Mataram secara eksplisit memunculkan kuatnya peran hakim dalam berijtihad dengan mengacu kepada pendapat pakar hukum Islam yang termaktub dalam Kitab I'anatuth Tholibin juz 4 halaman 254 yang dalam salinan perkaranya dituliskan sebagai berikut:

"Di dalam mendakwa telah menikah dengan seorang wanita maka harus dapat menyebutkan sahnya pernikahan dan syarat-syaratnya seperti wali nikah dan dua orang saksi yang adil".

Melalui pendapat pakar hukum Islam di atas, Majelis Hakim tingkat banding berpendapat bahwa perkara permohonan itsbat nikah di sini adalah perkara kontentiosa, dimana pada pemeriksaan tingkat pertama Hakim Tingkat Pertama tidak memeriksa saksisaksi, namun demikian hal ini tidak menjadi hambatan bagi Majelis Hakim Tingkat Banding untuk mengadili dan menjatuhkan putusan dengan amar mengadili sendiri mengabulkan permohonan Pemohon I / Pembanding I dan Pemohon II/ Pembanding II karena dalil-dalil yang dikemukakan oleh Para Pemohon dalam perkara permohonan itsbat nikah ini dianggap terbukti dengan 
tidak adanya bantahan oleh Termohon/ Terbanding.

Apabila digali lebih dalam, pendapat pakar hukum Islam tersebut bahwa Pemohon I/Pembanding I dan Pemohon II/Pembanding II tetap harus dapat menyebutkan sahnya pernikahan dan syarat-syaratnya seperti menyebutkan siapa yang menjadi wali nikahnya dan siapa yang menjadi saksi-saksi pernikahan tersebut, dan hal ini telah dijelaskan dan disebutkan oleh Pemohon I/ Pembanding I dan Pemohon II/ Pembanding II dengan secara terperinci dalam surat permohonannya.

Masih berjibaku pada salinan putusan, penulis kembali menemukan ijtihad majelis hakim Pengadilan Tinggi Agama Mataram yang menggunakan dalil dari kaidah fiqh yang artinya:

"Menolak mafsadat atau keburukan lebih utama dibanding meraih maslahat atau kebaikan".

Kaitannya dengan sejumlah perkara di atas adalah bahwa kaidah tersebut senantiasa menjadi pertimbangan dijatuhkannya sebuah putusan, apakah putusan tersebut nantinya akan mendatangkan maslahat dan mencegah terjadinya keburukan. Output ijtihad dengan adanya putusan hukum yang berisi mengabulkan atau tidak mengabulkan secara implisit hasil ijtihad itu mengingkinkan diperolehnya manfaat dan kepastian hukum dalam perkawinan mereka. (Manan, 2006) menyebutnya sebagai keniscayaan yang semestinya diraih dan bermanfaat bagi yang melaksanakannya.

Bahkan ini menjadi suatu yang harus disegerakan putusan hukumnya dikarenakan diantara perkara yang diajukan pemohon di atas pemohon telah diakruniai anak dari perkawinan poligami yang dilakukan secara sirri. Melalui putusan isbat nikah dalam perkawinan poligami di atas, sebagaimana yang disidangkan oleh Pengadilan Tinggi Agama Mataram, maka pernyataan sah perkawinan poligami pemohon akan menjadi kejelasan dan kepastian hukum dan status (nasab) anak-anak yang lahir dari hubungan perkawinan PemohonI/Pembanding I dengan Pemohon II/Pembanding II sehingga di masa depannya masing-masing anak dan hakhaknya dapat terlindungi secara adil.

Ijtihad hakim dalam memeriksa perkara-perkara di atas, telah memberikan pedoman (social control) tentang segala sesuatu yang berkaitan dengan perkawinan poligami. Produk Ijtihad dalam bentuk putusan hukum, baik yang dikeluarkan oleh Pengadilan Agama atau Pengadilan Tinggi Agama, telah mendorong terbentuknya perubahan pada level hukum dan juga pemahaman masyarakat mengenai kepatuhan bertindak hukum, terutama bagi yang berkepentingan, agar dapat melaksanakan perkawinan poligami sesuai dengan mekanisme hukum. Keikutsertaan masyarakat dalam mematuhi aturan perkawinan poligami dapat disebut sebagai salah satu keberhasilan dan jaminan atas adanya kepastian hukum. Dengan adanya kepastian hukum, maka susungguhnya hukum sedang berusaha manjauhkan setiap calon pengantin dari keragu-raguan dalam hal yang dapat menimbulkan kerusakan atau mafsadat. (Fadhli \& Rahmi, 2016) 


\section{KESIMPULAN}

Permohonan izin poligami adakalanya dikabulkan namun adapula tidak dikabulkan. Pada duduk perkara pemohon yang alasan izin poligaminya dikarenakan kebutuhan sexual, majelis hakim Hakim Pengadilan Agama Rembang, hakim Hakim Pengadilan Agama Sleman dan Hakim Pengadilan Agama Sukoharjo sekiranya memiliki pertimbangan yang sejalan antara mengacu pada landasan perundangundangan dan fiqh ketika mengabulkan permohonan pemohon. Sedangkan Hakim Pengadilan Agama Brebes, tidak serta merta mengabulkan izin poligami pemohon meskipun pemohon telah direstui oleh istri pemohon untuk menikah lagi. Pada situasi ini, hakim mencoba untuk keluar dari pertimbangan hukum primer dan menggunakan kewenangannya untuk bertindak contra legem.

Dengan memberikan penjelasan menggunakan dalil-dalil fiqh, menurut penulis majelis hakim berhasil memunculkan maslahat dengan kesadaran pemohon mencabut kembali permohonannya. Menurut penulis, Majelis Hakim Pengadilan Bima berhasil dalam memunculkan pertimbangan yang maslahat, meskipun tidak berangkat dari dalil-dalil fiqh. Aturan perundang-undangan justru lebih kental dalam putusan hukumnya. Namun, ketika perkara ini naik banding dan disidangkan di Pengadilan Tinggi Agama Mataram, hakim kembali bertindak contra legem dengan beralih pada pertimbangan hukum yang kental dengan dalil fiqh. Alasannya, perkara pemohon dinilai hakim sudah jauh lebih kompleks dari waktu yang sebelumnya. Permohonan yang diajukan dalam permohonan itsbat nikah Poligami ini kemudian dikabulkan dengan pelbagai argumentasi hakim yang syarat dengan pertimbangan-pertimbangan yang bersumber dari perundang-undangan, fiqh dan pakar hukum Islam.

\section{DAFTAR PUSTAKA}

Aisyah, N. (2018). Peranan Hakim Pengadilan Agama dalam Penerapan Hukum Islam di Indonesia. Al-Qadau, 5, 73-92.

Anshary, M. (2010). Hukum Perkawinan di Indonesia: Masalah-masalah Krusial. Pustaka Pelajar.

Budiharjo, E. W. (2013). Praktik Poligami Pegawai Negeri Sipil ditinjau dari Sistem Hukum Perkawinan. Pandecta : Jurnal Penelitian Ilmu Hukum (Research Law Journal), 8(1)

Bungin, B. (2007). Metode Penelitian Kualitatif (Aktualisasi Metodologis ke Arah Ragam Varian Kontemporer). Raja Grafindo Persada.

Fadhli, A., \& Rahmi, F. (2016). Intervensi Tuanku Terkait Praktek Nikah Siri di Nagari Kurai Taji Pariaman. 2, 155-178.

Hadi, S. (1985). Metodologi Research. Fakultas Psikologi UGM.

Hadikusuma, H. (1990). Hukum Perkawinan Indonesia Menurut Perundang-Undangan, Hukum Adat, Hukum Agama. Mandarmaju.

Handayani, S., Alfin, A., \& Daipon, D. (2019). Implementasi Undang-Undang nomor 1 Tahun 1974 Tentang Izin Poligami di Pengadilan Agama Bukittinggi (Studi Kasus Perkara Nomor 081/PDT.G/2013/PA.Bkt dan Perkara Nomor 0328/PDT.G.2015/PA/BKT). 
04(1)

M. Ichsan. (2018). Poligami Dalam Perspektif Hukum Islam (Kajian Tafsir Muqaranah). JURIS (Juris Ilmiah Syariah), 17(2)

Manan, A. (2006). Aneka Masalah Hukum Perdata Islam di Indonesia. Putra Grafika.

Mardani. (2010). Hukum Acara Perdata Peradilan Agama dan Mahkamah Syariah. Sinar Grafika.

Mu'ammar, M. A. et. all. (2012). Studi Islam Perspektif Insider/Outsider. IRCiSoD.

Muchali, R. (2005). Wacana Poligami di Indonesia. PT. Mizan.

Mushthofa, A. H. (2019). Ijtihad Hakim Dalam Penerapan Konsep Contra Legem Pada Penetapan Perkara di Pengadilan Agama. 1(2), 1-17.

Rogaiyah. (2010). Putusan Contra Legem Sebagai Implementasi Penemuan Hukum Oleh Hakim di Peradilan Agama ( Studi Kasus Putusan Kasasi Nomor 16 K/ AG / 2010 dan Putusan Kasasi Nomor 110 K / AG / 2007). 193-206.
Soemitro, R. H. (1985). Metodologi Penelitian Hukum. Ghalia Indonesia.

Soemitro, R. H. (1985). Metodologi Penelitian Hukum. Ghalia Indonesia.

Tiwana, M. M. (1972). al-Ijtihad wa Madha Hajatina Ilaih Fi Hadha al-'Asr. Daar alKutub.

Zahra, M. A. (n.d.). Ushul al-figh. Dar alFikr al-Arabi.

\section{Salinan Perkara}

Nomor 790/Pdt.G/2013/PA.SMN

Nomor 0663/Pdt.G/2014/PA.Bm

Nomor 0093/Pdt.G/2014/PTA.Mtr

Nomor 452/Pdt.G/2018/PA.Skh

Nomor 850/Pdt.G/2019/PA.Rbg

Nomor 304/Pdt.P/2020/PA.Bbs 